\title{
TAIWANESE UNIVERSITY STUDENTS' ATTITUDES TO NON-NATIVE SPEAKERS ENGLISH TEACHERS
}

\author{
Feng-Ru Chang \\ (bubukiki916@gmail.com) \\ The University of Queensland \\ Brisbane QLD 4072 Australia
}

\begin{abstract}
Numerous studies have been conducted to explore issues surrounding non-native speakers (NNS) English teachers and native speaker (NS) teachers which concern, among others, the comparison between the two, the self-perceptions of NNS English teachers and the effectiveness of their teaching, and the students' opinions on and attitudes towards them. Most of these studies have been conducted in ESL contexts in which the teachers are NNS English teachers, while most NNS English teachers actually work in EFL contexts. It is important that we understand issues on NNS English teachers in EFL contexts. Hence, this article aims to investigate university students' attitudes towards their NNS English teachers in Taiwan. The data were collected through questionnaires and interviews. The findings indicated that Taiwanese students' attitudes towards their NNS English teachers are positive and favorable and NNS English teachers are generally perceived as capable of delivering efficient instruction though some shortcomings of NNS English teachers were pointed out by participants. Discussion on these shortcomings and implications on Taiwan educational system and the qualifications of NNS English teachers is provided.
\end{abstract}

Keywords: EFL, non-native speakers (NNS) English teachers, native speakers (NS) English teachers, learners' perception, attitudes

DOI: http://dx.doi.org/10.15639/teflinjournal.v27i1/46-62

In Taiwan, English competence is viewed as a developmental aid, not only for the nation to build relations with political powers and maintain national economic competitiveness, but also for an individual to succeed in higher education and job market. This phenomenon is also pervasive in other Asian countries, such as China, Korea, Japan and so on. Due to the increasing popularity 
of English, many Asian countries develop English language teaching programmes which involve NS English teachers. Japanese government, for example, sponsored a programme which focuses on hiring Western native English speakers to work with Japanese ELT curricula. The program is called the Japan Exchange and Teaching Programme (JET, http://www.jetprogramme.org/). Korea had a similar program named English Programme (EPIK, http://www.epik.go.kr/). Taiwan government also developed the "Implementation Plan for Cooperation Teams Promoting English Language Teaching at Elementary and Junior High Schools" to recruit NS English teachers to address the urgent need of qualified teachers in line with the new English language policy "Grade One to Nine Curriculum", which requires that English be taught in the elementary school from Grade five starting in 2001 and Grade three in 2005 (Chang, 2008), creating 2000 new positions for English instructors. However, the quantity and the quality of NS English teachers remains a critical issue to this day and the NS English teachers' recruitment plan did not meet Taiwanese government's expectation. The plan called for an initial group of 369 NS English teachers to arrive to Taiwan, but only five of them came, and two of them left before finishing their contracts (Sun \& Li, 2004). The discrepancy between MOE's planned number of NS English teachers and the actual number has continued for several years (Tsai, 2009).

Although the policy of MOE did not work as expected, more and more private English cram schools, language centers, and private schools recruit English native speakers as English teachers to create the "whole English" contexts in which English is used as the medium for instruction. Classes instructed by NS English teachers are always popular with not only students but also their parents. Most of the people in Taiwan tend to believe that NS English teachers are better language learning models for learners than NNS English teachers merely because English is their first language. They also agree that students can learn English much better in NS English teachers' classes rather than in NNS English teachers' classes. Also, NS English teachers always get higher pay and receive more respect from students and their parents than NNS English teachers (Wu \& Ke, 2009). Some NNS English teachers even play a role as NS English teachers' assistants or tutors, responsible for translating what NS English teachers say in class into Chinese to help students' learning. It seems to imply that NS English teachers are superior to NNS English teachers.

However, some previous studies pointed out that NS and NNS English teachers are just two different groups of teachers and that NS English teachers 
are not superior to NNS English teachers (Medgyes, 1994; Braine, 2005; Ling \& Braine 2007; Wu \& Ke, 2009; Yeh \& Wang, 2009). Ling and Braine's research in Hong Kong (2007) showed students' positive attitudes towards NNS English teachers. They feel that the NNS English teachers perform as well as NS English teachers and they can learn from the NNS English teachers as well as from NS English teachers. NNS English teachers, based on that study in Hong Kong, are considered better in both 'ability to use students' mother tongue in teaching', particularly in explaining the problems the students have, and ' effective pedagogical skills' as they are knowledgeable of students' cultural background and the way Hong Kong students learn. Moreover, in Yeh and Wang's (2009) research in Taiwan, NNS English teachers are also regarded as good language learning models for students since they can share their own learning experiences with their students, anticipate learners' learning problems and use learners' first language to make effective communication.

With regard to Taiwanese context, Wu and Ke's (2009) research on Native Speakers English teachers show that there is a gap between Taiwanese students and NS English teachers. For example, students expect that there should be more interaction between them and NS English teachers, but NS English teachers express that students are very passive and reluctant to express their opinions, keep quiet all the time, and wait for teachers' answers instead. Such misunderstanding might have arisen because NS English teachers have little understanding about Taiwanese students' cultural background. In Taiwan, the traditional English teaching can be described as both teacher-centered and testdriven. Therefore, teachers control almost everything in the classroom and students are always taught to keep quiet in class even though they may have some questions. Under the pressure of examinations, students tend to ignore other things irrelevant to examinations. Hence, it is predictable that students are less independent and lack the ability to do critical thinking. Without this awareness, NS English teachers will find more difficulties in making their teaching effective and successful. In contrast, NNS English teachers can avoid such problem since they are quite familiar with how students learn and what students need. Therefore, the result of $\mathrm{Wu}$ and Ke's study supports Medgyes's perspective that NNS English teachers can serve as good, or even better, learning models since they generally have better understanding of what students need and how they learn.

With the influence of globalization and the increasing importance of English, more and more research have been conducted to explore issues on the 
comparison between NS English teachers and NNS English teachers in the field of English language learning and teaching. The primary focus of these studies is on exploring and discussing teachers' self-perceptions on English instruction (e.g. Arva \& Medgyes, 2000; Kamhi-Stein, 2004; Llurda, 2004, 2005; Medgyes, 1999; Moussu, 2000, 2006; Tsui \& Bunton, 2000), the differences of their professional abilities, the prestigious status of NS English teachers, the threats faced by NNS English teachers and so on (Ling \& Braine, 2007; Todd \& Pojanapunya, 2009; Wu \& Ke, 2009). However, less research has emphasized on investigating issues on these two groups of teachers from learners' perspectives. Furthermore, the majority of students around the world learn English and most English teachers work in EFL contexts. Therefore, some research on issues about these two groups of teachers conducted in the EFL contexts are needed. In Taiwan, English is the only foreign language tested in the entrance examinations and it is the most popular language that Taiwanese people desire to master (Tsou, 2013). Because of the privileged status of English in Taiwan, people pay more and more attention to the ways of improving English language learning. Additionally, most of the English classes are still instructed by NNS English teachers. Obviously, in order to improve English language learning in Taiwan, it is significant and necessary to explore issues on NNS English teachers.

Hence, this article addresses the need of a comprehensive and in-depth investigation of university students' attitudes towards their NNS English teachers in Taiwan by virtue of the growing importance of English. To specify, the study addresses these two questions: (1) What are the attitudes of university students in Taiwan towards NNS English teachers?; and (2) What are the students' expectations of NNS English teachers?

\section{METHOD}

The participants of the study were 200 undergraduates who had had experiences of being taught by Taiwanese NNS English teachers and NS English teachers. They were all freshmen from a university in the south part of Taiwan and the research was conducted in 2013.

In order to investigate the students' attitudes to and expectations of NNS English teachers, the present research was conducted in two phases, a questionnaire survey followed by an interview. Questions in a questionnaire are generally limited and it is difficult to obtain more in-depth responses (Munn \& 
Drever, 1990). However, participants can further express or explain their opinions in the interview; in this way, the interview data can complement and elaborate that from the questionnaire. For this reason, both questionnaire and interview were adopted in this research to collect more useful and objective data.

The questionnaire used in Ling and Braine's study in 2007 was adopted for this research because of its suitability to the context of the study. The questionnaire in Ling and Braine's research was modified from the International Teaching Assistants (QUITA) questionnaire which was designed and used by Plakans (1997) to collect background information about undergraduate students' opinions towards international teaching assistants, including their experience with international teaching assistants, their attitudes towards courses conducted by international teaching assistants, their cross-cultural awareness, and their willingness to take the responsibility for the interaction in classes taught by international teaching assistants (Ling \& Braine, 2007). A lot of studies have adopted the International Teaching Assistants (QUITA) questionnaire to investigate students' attitudes towards non-native English teachers in many different countries.

The questionnaire consists of four sections. The first section focused on the target subjects' background information, such as gender, experience, number of years of previous study of English, and their major. The second part of the questionnaire intends to ask about the subjects' experience with non-native English teachers. The following section emphasizes on exploring students' attitudes towards non-native English teachers from two perspectives: communication with NNS English teachers and learning from NNS English teachers. The last part of the questionnaire was designed to elicit subjects' expectations of NNS English teachers from linguistic and cultural aspects.

Before the questionnaire was administered to a larger group of subjects in the main study, a pilot study was done with fifty randomly selected university students. In the pilot study, students were asked to underline some terms or words that they could not understand when filling in the questionnaire. Most of them responded that they did not understand the terms like ESL, NNS English teachers and non-native English teachers. Therefore, before copies of the questionnaire were given to the students, I explained the meanings of the terms that caused difficulties in the pilot study to ensure every participant understands the terms used in the questionnaire. There were two hundred copies of the questionnaire returned in total. 
The follow-up interview was held two weeks later. It was conducted in Mandarin with ten of the participants in the questionnaire survey who volunteered to have the interview. It lasted half an hour, and the questions revolved around issues on the shortcomings and merits of NNS English teachers based on the students' learning experience. The interview was recorded under the students' permission and was translated into English for analysis.

\section{FINDINGS AND DISCUSSION}

Table 1 and 2 present the results of the questionnaire concerning the students' attitude to NNS English teachers in terms of their communication with the teachers, and their learning from them. Even though there were four choices for each question, I categorized them into only two categories, "agree" and "disagree", in order to make the results more apparent and much easier to investigate students' attitudes towards NNS English teachers in Taiwan. This study was designed to be primarily descriptive, so the numerical data from the questionnaire were not intended to be strictly quantitative and they were presented by percentage to indicate some common traits in students' attitudes to NNS English teachers.

Table 1. Communication with NNS English teachers

\begin{tabular}{llc}
\hline \multicolumn{1}{c}{ Question } & \multicolumn{1}{c}{$\begin{array}{c}\text { Agree/ } \\
\text { Disagree }\end{array}$} & $\begin{array}{c}\text { Number of } \\
\text { students } \\
\text { (Percentage) }\end{array}$ \\
\hline $\begin{array}{l}\text { 1. If I had trouble understanding a non-native Eng- } \\
\text { lish instructor, I would talk with her or him about } \\
\text { it during office hours. }\end{array}$ & Agree & $160(80 \%)$ \\
\hline $\begin{array}{l}\text { 2. Many non-native English instructors usually } \\
\text { communicate effectively in the classroom. }\end{array}$ & Agree & $194(97 \%)$ \\
\hline $\begin{array}{l}\text { 3. I make friends with my native English } \\
\text { instructors more than my non-native } \\
\text { English instructors. }\end{array}$ & Agree & $140(70 \%)$ \\
\hline $\begin{array}{l}\text { 4. When there are communication problems } \\
\text { between students and non-native English } \\
\text { instructors, students cannot do anything to im- } \\
\text { prove the situation. }\end{array}$ & Disagree & $180(90 \%)$ \\
\hline 5. I feel comfortable talking about personal & Agree & $130(65 \%)$ \\
\hline
\end{tabular}




\begin{tabular}{llc}
\hline \multicolumn{1}{c}{ Question } & $\begin{array}{c}\text { Agree/ } \\
\text { Disagree }\end{array}$ & $\begin{array}{c}\text { Number of } \\
\text { students } \\
\text { (Percentage) }\end{array}$ \\
\hline concerns with non-native English instructors. & & \\
\hline $\begin{array}{l}\text { 6. On the whole, non-native English instructors } \\
\text { show about the same level of concern for students } \\
\text { as do native English instructors. }\end{array}$ & Agree & $180(90 \%)$ \\
\hline * Percentage in each cell (N=200) & &
\end{tabular}

Table 2. Learning from NNS English teachers

\begin{tabular}{llc}
\hline \multicolumn{1}{c}{ Question } & $\begin{array}{c}\text { Agree/ } \\
\text { Disagree }\end{array}$ & $\begin{array}{c}\text { Number of } \\
\text { students } \\
\text { (Percentage) }\end{array}$ \\
\hline $\begin{array}{l}\text { 7. If I got a non-native English instructor } \\
\text { with a weak foreign accent, I would try to } \\
\text { transfer to another course. }\end{array}$ & Agree & $176(88 \%)$ \\
\hline $\begin{array}{l}\text { 8. I can learn just as well from a non-native } \\
\text { English instructor as I can from a native } \\
\text { English instructor. }\end{array}$ & Agree & $176(88 \%)$ \\
\hline $\begin{array}{l}\text { 9. Students' attitudes affect their ability to } \\
\text { understand non-native English instructors } \\
\text { in class. }\end{array}$ & Agree & $190(95 \%)$ \\
\hline $\begin{array}{l}\text { 10. If I could choose the course myself, I } \\
\text { would choose a course taught by a non- } \\
\text { native English instructor. }\end{array}$ & Agree & $116(58 \%)$ \\
\hline $\begin{array}{l}\text { 11. Many non-native English instructors have } \\
\text { difficulty understanding and answering } \\
\text { students' questions. }\end{array}$ & Disagree & $170(85 \%)$ \\
\hline $\begin{array}{l}\text { 12. It would be better if non-native English } \\
\text { instructors were not allowed to teach in }\end{array}$ & Disagree & $114(57 \%)$ \\
\hline $\begin{array}{l}\text { ESL programmes. } \\
\text { 13. There are many non-native English in- } \\
\text { structors who teach just as effectively as } \\
\text { native English instructors. }\end{array}$ & Agree & $188(94 \%)$ \\
\hline * Percentage in each cell (N=200) & &
\end{tabular}

The results of the survey indicated that most of the students showed favourable and positive attitudes toward NNS English teachers as based on the NNS English teachers' teaching performance in class and their shared back- 
ground with the students. For example, in answering questions $8(88 \%)$ and 13 (94\%), students showed their agreement that they can learn from NNS English teachers as well as from NS English teachers, and NNS English teachers teach as effectively as NS English teachers.

Moreover, based on the students' answers to questions 1, 3, 5 and 6, students' attitudes towards NNS English teachers were favourable due to the same cultural background and language shared with their teachers. For example, the results of the questions $1(80 \%), 3(70 \%)$ and $5(65 \%)$ in the questionnaire indicated that students did not have trouble communicating with NNS English teachers inside and outside the classroom, or even make friends with NNS English teachers.

To sum up, from the analysis of the questionnaire which focused on students' communication with NNS English teachers and learning from NNS English teachers, most of the students indicated that they did not encounter problems in both communicating and learning with NNS English teachers. In particular, the participants strongly agreed that NNS English teachers' understanding of and answering their questions were great. Generally, the university students tended to agree that NNS English teachers can both communicate with their students well and teach as effectively as NS English teachers. Therefore, it is apparent that most of the Taiwanese students in this survey had positive attitudes towards NNS English teachers. Furthermore, more than half of the students agreed that they preferred to learn English under the instruction of NNS English teachers rather than NS English teachers, which is against the native speakers model that NS English teachers is superior to NNS English teachers (Tang, 1997). The results also confirmed Medgyes' findings that NNS English teachers can be a good language learning model for learners because of their good understanding of the students' language, and culture and their experience of being second language learners (Medgyes, 1994).

Table 3 presents the results of the questionnaires concerning the students' learning experiences with Taiwanese NNS English teachers.

Table 3. Students' Learning Experiences with NNS English Teachers

\begin{tabular}{ccc}
\hline Question & $\begin{array}{c}\text { Agree/ } \\
\text { Disagree }\end{array}$ & $\begin{array}{c}\text { Number of } \\
\text { students } \\
\text { (Percentage) }\end{array}$ \\
\hline $\begin{array}{c}\text { 14. I think that the NNS English teachers will pay } \\
\text { more attention to grammar. }\end{array}$ & Agree & $176(88 \%)$ \\
\hline
\end{tabular}




\begin{tabular}{|c|c|c|}
\hline Question & $\begin{array}{c}\text { Agree/ } \\
\text { Disagree }\end{array}$ & $\begin{array}{c}\text { Number of } \\
\text { students } \\
\text { (Percentage) }\end{array}$ \\
\hline $\begin{array}{l}\text { 15. The NNS English teachers' teaching style is } \\
\text { easy for me to follow. }\end{array}$ & Agree & $169(80 \%)$ \\
\hline $\begin{array}{l}\text { 16. The NNS English teachers' pronunciation is } \\
\text { much easier for me to understand. }\end{array}$ & Agree & $134(67 \%)$ \\
\hline $\begin{array}{l}\text { 17. The accent of the NNS English teachers is } \\
\text { easy to understand. }\end{array}$ & Agree & $130(65 \%)$ \\
\hline $\begin{array}{l}\text { 18. The NNS English teachers will pay less } \\
\text { attention to correcting my pronunciation. }\end{array}$ & Agree & $122(61 \%)$ \\
\hline $\begin{array}{l}\text { 19. The NNS English teachers tend to correct the } \\
\text { grammatical mistakes I made. }\end{array}$ & Agree & $168(84 \%)$ \\
\hline $\begin{array}{l}\text { 20. The teaching materials prepared by NNS } \\
\text { English teachers are much understandable for } \\
\text { me to follow. }\end{array}$ & Agree & $172(86 \%)$ \\
\hline $\begin{array}{l}\text { 21. The NNS English teachers' speaking speed is } \\
\text { not too fast to follow. }\end{array}$ & Agree & $168(84 \%)$ \\
\hline $\begin{array}{l}\text { 22. The NNS English teachers can not help me to } \\
\text { learn more about the culture of the target } \\
\text { language. }\end{array}$ & Disagree & $118(59 \%)$ \\
\hline $\begin{array}{l}\text { 23. There will be less interaction between the } \\
\text { NNS English teachers and the students in } \\
\text { class. }\end{array}$ & Disagree & $152(76 \%)$ \\
\hline $\begin{array}{l}\text { 24. The NNS English teachers will use some } \\
\text { Chinese in class to help students to learn } \\
\text { when most of the students reflect that they do } \\
\text { not understand what the teachers are teaching. }\end{array}$ & Agree & $190(95 \%)$ \\
\hline $\begin{array}{l}\text { 25. The teaching performance of NNS English } \\
\text { teachers is as good as native speaker English } \\
\text { teachers. }\end{array}$ & Agree & $172(86 \%)$ \\
\hline $\begin{array}{l}\text { 26. The NNS English teachers can know my } \\
\text { needs and learning problems. }\end{array}$ & Agree & 186 (93\%) \\
\hline
\end{tabular}

* Percentage in each cell $(\mathrm{N}=200)$

Based on the results in Table 3, generally, most of the students' attitudes towards NNS English teachers were high. The data were analyzed in terms of three aspects: NNS English teachers' teaching style, linguistic performance and understanding of culture. Firstly, concerning NNS English teachers' teaching 
style, such as the ways they lead the class, a high percentage of the students indicated that NNS English teachers' teaching style is easier for the students to follow and understand. In particular, the students' answers to question 24 $(95 \%)$ showed that almost all of the participants agreed that it is effective and helpful for them to understand teachers' instruction when NNS English teachers use Chinese to explain the difficulties they encounter. It further implied that proficiency in the learners' mother tongue is very important in the contexts of teaching EFL as stated by Medgyes (1994). However, most of the NS English teachers do not have such proficiency of learners' first language. Furthermore, the result of question $20(86 \%)$ showed that the materials prepared by NNS English teachers were more comprehensible for the students. It might possibly be due to the shared cultural background between teachers and students, which allowed the teachers to select and/ or develop materials that suit the students' levels and interests (Ling \& Braine, 2007).

From the linguistic point of view, the linguistic traits of NNS English teachers are easier for learners to follow, such as, in terms of speaking speed and pronunciation. Furthermore, it is apparent that NNS English teachers paid more attention to syntactic mistakes made by learners based on the responses to questions $14(88 \%)$ and $19(84 \%)$. I think that NNS English teachers tend to emphasize more on the syntactic, but not phonetic part, because the educational system in Taiwan is test-driven orientation. For this reason, NNS English teachers tend to focus more on teaching grammar and correcting learners' grammatical mistakes to help them pass the exams. This test-driven teaching results in students' ignorance of the importance of listening and speaking ability, which further leads to students' unsatisfactory English proficiency.

With regard to the understanding of English culture, students also showed positive attitudes towards NNS English teachers. The result indicated that NNS English teachers can also help students understand the culture of English even though they are not English native speakers.

The results of the interview with ten voluntary students complement and further elaborate the results of the questionnaire. The interview questions concern NNS English teachers' strengths and shortcomings based on the students' experience with NNS English teachers as well as their perception of them. Athematic analysis (Holstein \& Gubrium, 1997) was adopted in this study to analyze the interview data. The data were discussed and presented in terms of NNS English teachers' strengths and shortcomings, accompanied by excerpts from the students' responses in the interview. 
With regard to NNS English teachers' strengths, the students pointed out that NNS English teachers' ability to use their mother tongue in the classroom is really helpful for the students to overcome learning difficulties they faced and make their learning more effective. For example, one of the interviewees mentioned:

My NNS English teacher always uses Chinese to explain more difficult parts in her teaching. She tends to use Chinese, not English, when most of the students in the class show that they do not understand what she is teaching. I think that it is an effective way for me to learn English. (Student H)

In addition, with the help of the shared language between NNS English teachers and their students, students pointed out that they could feel more relaxed and less anxious in the classroom as what Student E stated:

I think it is really helpful for me to learn well that the NNS English teacher can use Chinese in teaching, which can help me to feel more relaxed and less nervous in the class. (Student E)

Moreover, from the students' perception, NNS English teachers are able to share their own EFL learning experiences and understand their students' learning problems since they themselves were EFL learners and experienced the same learning difficulties, which makes them possibly more empathetic than NS English teachers and be able to provide their students with suggestions on useful language learning strategies. For example, Student B and D remarked:

My NNS English teacher can provide me with a lot of learning strategies because she had been an English learner in an EFL environment before. She taught me how to memorize vocabulary well and use these words I learned to make sentences. (Student B)

I can learn a lot from my NNS English teacher because she is always willing to discuss learning strategies with me. She also likes to share her English learning experience with me. I think her experience really helps me a lot in the language learning process. (Student D) 
In addition to sharing useful language strategies with their students, NNS English teachers are thought to be aware of their students' needs during the language learning process.

I think that my NNS English teacher always knows what my needs and my learning problems are. For example, he knows that most of the students in Taiwan are under the pressure of the examinations, so he tends to put more focuses on the grammar to meet our needs. (Student J \& H)

In order to meet the trend of passing the GEPT or TOEIC policy in Taiwan, my NNS English teacher tends to emphasizes more on how to help me to pass the English test or explain more about it. (Student A)

Taiwanese NNS English teachers' test-driven teaching, on one hand, is good for students because they understand clearly the students' needs and problems. But, on the other hand, the over-emphasis on passing the examinations always leads to the unbalanced development of English language four skills.

Based on the above discussion, generally students have favorable attitude toward NNS English teacher. However, students in the interview also pointed out some shortcomings of NNS English teachers based on their teaching performance and their linguistic competence. First of all, in terms of NNS English teachers' teaching performance, students mentioned that the teachers tend to adopt test-oriented teaching approach and they correct almost every grammatical mistake their students make as what Student $\mathrm{E}$ and $\mathrm{H}$ mentioned below:

Because we face the pressure to pass the examinations, such as, GEPT, TOEIC, College Entrance Examination etc., the teacher tends to use the spoon-feed teaching approach to instruct the class. (Student E)

My English teacher likes to correct almost every grammatical mistake I made in class, which makes me feel very nervous and anxious when I want to express my opinions in class. (Student H)

Secondly, based on the results of the questionnaire, most of the NNS English teachers were criticized for their pronunciation and accents which are always viewed as their drawbacks, and the participants in the interview also pointed this out as shown below: 
The teacher's pronunciation is easier to understand and more familiar to me. Though I can understand my teacher well in class, it is still very difficult for me to understand the accents or pronunciation of native speakers. I think it would be better if my NNS English teacher can have an accent like native speakers. (Student E)

NNS English teachers' test-driven teaching style further manifested two disadvantages of the educational system in Taiwan. First of all, under the Taiwanese assessment system that emphasizes mainly on reading and writing, apparently, the development of English listening and speaking abilities have been ignored for a long time. Since 1994, the "communicative approach" has been adopted as the main principle in the curriculum, attempting to balance the development of speaking, listening, reading, and writing. Unfortunately, listening and speaking have not reached the popular status as reading and writing do due to the assessment system which still emphasizes mainly on reading and writing. The lack of practice in listening and speaking leads to students' poor listening and speaking abilities. A lot of scholars, university professors and English teachers have been complaining about students' poor listening and speaking abilities (Chen \& Tsai, 2012). In response to this problem, since 2014, Ministry of Education in Taiwan has included English listening as a formal and compulsory part of Comprehensive Assessment Program for Junior High School Students. Moreover, English was an optional part in the College Entrance Examination since 2013 and it has become compulsory since 2015. However, though English listening has been adopted as a formal part of the entrance examinations, it is still not given adequate attention in the classroom due to its small proportion in the exams compared to reading and writing. Besides listening, speaking instruction has long been marginalized in Taiwan and did not receive much attention due to the fact that English speaking is not tested for school entry. The assessment system of Taiwan education system, in my opinion, leads to NNS English teachers' over-emphasis on the importance of grammatical correction and reading skills because they face the great pressure of the two main entrance examinations. The test-driven teaching style of NNS English teachers points out the unbalanced development of English competence in Taiwan English education. The balanced development of English four skills should be taken into careful consideration in designing the English curricula and the assessment systems of English ability. 
Furthermore, because of NNS English teachers' test-driven instruction, they are always classified as being good at teaching grammar only. Under the extreme pressure of two entrance examinations, Comprehensive Assessment Program for Junior High School Students and College Entrance Examination, not only teachers but also students devote themselves to cultivating reading and writing skills in order to get good grades to enter their ideal universities. However, this does not mean that NNS English teachers are capable of teaching grammar only or that they like to teach grammar. It also reminds us that NNS English teachers should not be confined to being responsible for grammar only as a lot of them do so in some private cram schools or language centres.

\section{CONCLUSIONS AND SUGGESTIONS}

Based on the findings, the participating students showed very positive attitudes towards their NNS English teachers, which corresponds to the findings of the previous studies like Mahboob (2004), Moussu and Braine (2006), Ling and Braine (2007), and so on. They also felt that NNS English teachers can serve as good English language learning models for them because of their own foreign language learning experiences. Moreover, NNS English teachers' teaching performance was also considered to be as good as or even better than NS English teachers' performance because they can use their students' first language in teaching, anticipate their learning difficulties and share useful language learning strategies with them, which corresponds to what Medgyes (1994) states, that NNS English teachers are able to share effective learning strategies, anticipate language difficulties, and understand the learners' needs and problems.

Apart from the positive and favorable attitudes towards NNS English teachers, students also pointed out some of their drawbacks, such as test-driven teaching style, non-authentic pronunciation, and over-correcting students' grammatical mistakes. Those shortcomings of NNS English teachers are, on the other hand, the strengths of NS English teachers. However, the merits of NNS English teachers discussed above are the drawbacks of NS English teachers. The results of this study thereby support Medgyes (1994, p. 25) that NS and NNS teachers are just "two different species". It further implies that NS English teachers are not superior to NNS English teachers, and they are just two different groups of teachers who differ in terms of language proficiency and teaching practice. Both NS and NNS English teachers could be equally 
good teachers on their own terms (Ling \& Braine, 2007). Moreover, students' positive attitudes towards NNS English teachers in this study indicate that NNS English teachers are generally perceived capable of delivering efficient instruction, and their students benefit from not only their instruction but also their learning strategies.

Such research findings should make changes in the beliefs of the proponents of "nativism", which may further lead to changes in actions (Tong \& Cheng, 2006), in which NNS English teachers are treated as equally and respectfully as NS English teachers, and raise the awareness of the public that NNS English teachers are not inferior to NS English teachers in knowledge, professional skills, and so on.

Concerning the test-driven instruction indicated in this study as the NNS English teachers' major drawback, not only teachers but also students should be aware of the importance of the balanced development of English language four skills simultaneously instead of ignoring speaking and listening skills, which needs to be supported by the schools and government.

Finally, it is suggested that further researchers interested in doing similar studies expand the number and range of the subjects. It would also be worthy to explore both teachers' and students' opinions to make the research more complete and fruitful.

\section{REFERENCES}

Arva, V., \& Medgyes, P. (2000). Native and non-native teachers in the classroom. System, 28(3), 355-372.

Braine, G. (Ed.). (2005). Teaching English to the world: History, curriculum, and practice. Mahwah, NJ: Laurence Erlbaum Associates.

Chang, Y. F. (2008). Parents' attitudes toward the English education policy in Taiwan, Asia Pacific Education Review, 9(4), 423-435.

Chen, S. C., \& Tsai, Y. C. (2012). Research on English teaching and learning: Taiwan (2004-2008). Language Technology, 45(2), 180-201.

Holstein, J. A., \& Gubrium, J. F. (1997). Active interviewing. In P. Silverman (Ed.), Qualitative research: Theory, method and practice. London: Sage. 
Kamhi-Stein, L. D. (Ed.). (2004). Learning and teaching from experience: Perspectives on Non-native English-speaking professionals. Ann Arbor, MI: University of Michigan Press.

Ling, C. Y., \& Braine, G. (2007). The attitudes of university students towards non-native speakers English Teachers in Hong Kong. RELC Journal 38, 257-277.

Llurda, E. (2004). Non-native-speaker teachers and English as an international language. International Journal of Applied Linguistics, 14(3), 314-323.

Llurda, E. (2005). Non-native TESOL students as seen by practicum supervisors. In E. Llurda (Ed.), Non-native language teachers: Perceptions, challenges, and contributions to the profession (pp. 131-154). New York: Springer.

Mahboob, A. (2004). Native or nonnative: What do students enrolled in an intensive English program think? In L. D. Kamhi-Stein (Ed.), Learning and teaching from experience: Perspectives on nonnative English speaking professionals (pp. 121-147). Ann Arbor, MI: University of Michigan Press.

Medgyes, P. (1994). The non-native teacher. London: Macmillan publisher.

Medgyes, P. (1999). Language training: a neglected area in teacher education. In G. Braine (Ed.), Nonnative educators in English language teaching (pp. 93-104). Mahwah, NJ: Erlbaum.

Moussu, L. (2000). Native versus nonnative speakers of English: Students' reactions. Retrieved from http://www.moussu.net/courses/protfolio/540.pdf \#search='lucie\%20moussu\%20lin guistic\%20540

Moussu, L. (2006). Native and nonnative English speaking English as second language teachers: Student attitudes, teacher self-perceptions, and intensive English program administrator beliefs and practices (Doctoral dissertation, Purdue University, Indiana, USA). Retrieved from ERIC Database.

Moussu, L. \& Braine, G. (2006) The attitudes of ESL students towards nonnative English language teachers. TESL Reporter, 39(1), 33-47.

Munn, P., \& Drever, E. (1990). Using questionnaires in small-scale research. Edinburgh: The Scottish Council for Research in Education. 
Plakans, B. (1997). Undergraduates' experiences with and attitudes toward international teaching assistants, TESOL Quarterly, 31(1), 95-119.

Sun, R. H., \& Li, M. Y. (2004, December 15). Among the first 5 foreign teachers arrived, 2 have left. United Daily News, p. C8.

Tang, C. (1997). The identity of the nonnative ESL teacher: On the power and status of nonnative ESL teachers. TESOL Quarterly, 31(3), 577-580.

Todd, W. R., \& Pojanapunya, P. (2009). Implicit attitudes towards native and non-native speaker teachers. System, 37(1), 23-33.

Tong, C. W., \& Cheng, M-Y. (2006). The learning process of teaching beliefs: A case study. Paper presented in Three Places across Two Shores Seminar: School reform and cooperation, Hong Kong Chinese University, Hong Kong.

Tsai, P-L. (2009). Best practices of team teaching by native speaker teachers and non-native speaker teachers in Taiwanese junior high school English classes. (Doctoral dissertation, Alliant International University, San Diego, USA).

Tsou, S-Y (2013). Taiwanese university students' perceptions towards native and non-native English-speaking teachers in the EFL contexts. (Doctoral dissertation, Texas A \& M University, College Station, USA).

Tsui, A. B. M., \& Bunton, D. (2000). The discourse and attitudes of English language teachers in Hong Kong. World Englishes, 19(3), 287-303.

Wu, K-H., \& Ke, C. (2009). Haunting native speakerism? Students' perceptions towards native speaking English teachers in Taiwan. English Language Teaching, 2(3), 44-52.

Yeh, C-Y., \& Wang, Y-H. (2009). Native and non-native English speaking teachers' beliefs and their influence on their practice: A case study of elementary team-teaching in Hsin Chu City. Taiwan Journal of TESOL, 6(2), 93-120. 